duodenum cannulae were disconnected, and the abomasum emptied and rinsed before the experimental meals, in order to eliminate any pancreatic juice which might flow back. Samples were taken from the duodenum for 12 consecutive hours, accompanied by a simultaneous reintroduction of the contents. When the animals were fed a lipid-rich diet ( 57 samples taken during 7 sampling days), a high proportion of free fatty acids leaving the abomasum was always observed (24 p. roo on the average, the extreme values being 6 and 42 ). This was probably due to a hydrolysis of the dietary triglycerides in the abomasum. In fact, when the animals were fed a lipid free diet, the amount of lipids released in the abomasum was very low (I p. Ioo of the dry matter). Moreover, these lipids were very rich in phospholipids ( $37 \mathrm{p}$. Ioo on the average) while, on the lipid-rich diet, there were practically no phospholipids present. In addition, they contained higher proportions of linoleic acid than the corresponding fractions obtained after the ingestion of the lipid-rich diets.

It therefore seems that in the preruminant calf, there is a "lipase " capable of hydrolyzing long chain triglycerides in the abomasum. This lipase differs from the pregastric esterase, because GROSSKOPF ( 1965 ) has shown that, in vitro, the latter enzyme only acts on triglycerides containing butyric acid, liberating this acid only. This lipase is quite active because the amount of fatty acids it liberates, corresponds approximately to $5^{\circ} \mathrm{p}$. I 100 of that probably released by pancreatic lipase. In contrast to pancreatic lipase, this other lipase does not seem to have an intramolecular specificity, since the partial glycerides formed have a very similar fatty acid composition to that of the dietary triglycerides (table 1 ). The mode of action and the site of secretion of this enzyme remain to be described.

\title{
RÉFÉRENCE BIBLIOGRAPHIQUE
}

Grosskopf J. F. W., I965. Studies on salivary lipase in young ruminants. Onderstepoort J. Vet. Res. 32, I53-180.

\section{UTILISATION DIGESTIVE DU CALCIUM GHEZ LE PORC ET LE LAPIN QUELQUES FACTEURS DE VARIATION}

\author{
P. BESANÇON et L. GUÉGUEN \\ Station de Recherches de Nutrition, \\ Centre national de Recherches zootechniques, I. N. R. A., \\ 78 - Jouy-en-Josas
}

On sait, à la suite des travaux de nombreux auteurs, que le niveau d'ingestion calcique a une grande influence sur l'absorption du calcium. Par ailleurs, la rétention et le renouvellement du calcium osseux sont fonction du calcium absorbé, donc de l'apport exogène de $\mathrm{Ca}$. Chez le Porc en croissance, en augmentant les niveaux d'apport calcique de 8 à $17 \mathrm{~g} / \mathrm{kg}$ d'aliment, on diminue le CUDr ${ }^{(1)}$ de 45 à 38 p. Ioo; cependant, la rétention calcique est augmentée : en effet, la mobilisation du calcium osseux est alors 4 fois plus faible, tandis que l'anabolisme osseux n'est que légèrement accru. Chez le Lapin en croissance, les CUDr sont toujours beaucoup plus élevés 
que dans les autres espèces. L'augmentation des apports calciques de 8 à $\mathbf{1} 7 \mathrm{~g} / \mathrm{kg}$ entraîne une diminution du CUDr (67 à 57 p. I0o); la rétention est alors accrue (de 16 à 25 p. 100), par suite d'une moins importante mobilisation du calcium osseux alors que l'incorporation de Ca dans l'os est un peu augmentée. Les résultats obtenus sur le Lapin laissent supposer que les niveaux d'apport calcique sont un peu trop élevés. Chez l'animal adulte, on observe une réduction de l'absorption calcique : le CUDr n'est plus que de $8 \mathrm{p}$. roo chez la Truie au repos, mais il reste encore très élevé (5o p. 100) chez la Lapine. Malgré une rétention faible ou nulle, le calcium osseux se renouvelle encore de façon appréciable.

Les résultats montrent comment les voies d'utilisations digestive et métabolique sont liées. L'augmentation des apports calciques réduit toujours l'utilisation digestive du calcium et ralentit le renouvellement de la phase minérale osseuse. Chez le Lapin, cependant, l'absorption est toujours importante, même lorsque la rétention est faible par suite d'une fixation osseuse moindre ou de pertes accrues de calcium endogène par les voies d'excrétion. L'estimation de ces paramètres devrait permettre de mieux préciser les besoins en calcium et d'éviter les excès de calcium alimentaire.

\section{SUMMARY}

\section{DIGESTIVE UTILIZATION OF CALCIUM IN THE PIG AND THE RABBIT : SOME FACTORS OF VARIATION}

It has been shown by many authors that the level of the calcium intake has a great influence upon the calcium absorption. Moreover, the retention and turnover of the bone calcium depend upon the calcium absorbed, consequently upon the supply of exogenous Ca. When increasing the calcium supply in the growing pig from $8-\mathrm{I} 7 \mathrm{~g} / \mathrm{kg}$ food, the CUDr $\left(^{2}\right)$ decreases from 45 to $38 \mathrm{p}$. 100 ; the calcium retention, however, increases ; the mobilization of bone calcium is, indeed, 4 times lower, whereas the bone anabolism is only slightly increased. In the growing rabbit, the CUDr is always much higher than in the other species. The increase of the calcium supply from 8 to I $7 \mathrm{~g} / \mathrm{kg}$ induces a decrease of the CUDr (from 67 to $57 \mathrm{P}$. I00) ; the calcium retention is then increased (from I6 to 25 p. IOo) due to a less important mobilization of bone calcium, whereas the accretion of $\mathrm{Ca}$ in the bone is a little increased. The results obtained in the rabbit lead to the supposition that the levels of the calcium supply are a little too high. In the adult animal, a reduction of the calcium absorption is observed : the CUDr is only 8 p. Ioo in the non lactating and non pregnant sow, but still remains very high ( $50 \mathrm{p}$. 100) in the rabbit. In spite of a low retention or no retention, the turnover of the bone calcium is still important.

The results show how the pathways of the digestive and metabolic utilizations are bound together. Increase of the calcium supply always reduces the digestive utilization of calcium and decreases the turnover of the mineral phasis of the bone. However, in the rabbit, the absorption is always important even when the retention is low, a fact which is due either to a less important fixation of $\mathrm{Ca}$ in the bone or to higher endogenous losses of calcium. By means of these parameters it should be possible to define more accurately the calcium requirement and to avoid excess of dietary calcium.

(1) Coefficient d'utilisation digestive réelle.

(2) True digestive utilisation coefficient. 